\title{
Na boca do outro - o riso na psicose
}

\section{In other's mouth - the laugh in the psychosis}

\section{Carolina Gubert Viola*}

Mestranda em Educação da Universidade Federal do Rio Grande do Sul - UFRGS, Porto Alegre, RS, Brasil

\section{Mario Fleig**}

Docente do Programa de Pós-graduação de Filosofia da Universidade do Vale do Rio dos Sinos - UNISINOS, São Leopoldo, RS, Brasil

\begin{abstract}
RESUMO
O riso, desde Freud, figura como manifestação ímpar do inconsciente. A psicose, a partir de Lacan, ganha lugar especial na clínica psicanalítica. Como em psicanálise sem clínica não se faz teoria, aqui o relevante das surpresas advindas desta fomentaram o estudo proposto. O que se passa quando o riso eclode em sujeitos estruturados na psicose? Das diferentes formas de provocálo daremos aqui prioridade ao cômico em sua relação com a queda do significante fálico, este que parece siderar o sujeito psicótico. Indispensável à psicanálise o estatuto ético desta na transposição do trágico pelo cômico e no ato analítico enquanto via para que a voz do sujeito se faça ouvir vem a perguntar sobre isso: será o riso uma possível queda da voz enquanto objeto a tornar-se comunicação?
\end{abstract}

Palavras-chave: Riso, Sideração, Psicose, Voz

\section{ABSTRACT}

The laugh since Freud figures as an odd manifestation of the unconscious. The psychosis, in Lacan, acquires a special place in the thought and in the clinical psychoanalytical. As in psychoanalysis the theory comes from the clinical, the present paper also is a resulting of the surprises of clinical experiences. What happens when the laugh emerges in subjects structured in the psychosis? Among the different forms of provoking the laugh, this present paper will give priority to the comic in its relation to the fall of the significant phallus, which seems to fulminate the psychotic subject. The ethical statute indispensable to the psychoanalysis occurs in the analytical act as a possibility for the subject to be heard: would it be the laugh a possible fall of the voice as object? If so the voice in the laugh could be understood as communication?

Keywords: Laugh, Psychosis, Sideration, Voice 


\title{
Introdução
}

\begin{abstract}
Estava rindo, quente, quente. Pequena Flor estava gozando a vida. A própria coisa rara estava tendo a inefável sensação de ainda não ter sido comida. Não ter sido comida era algo que, em outras horas, Ihe dava o ágil impulso de pular de galho em galho. Mas, neste momento de tranqüilidade, entre as espessas folhas do Congo Central, ela não estava aplicando esse impulso numa ação - e o impulso se concentrara todo na própria pequenez da própria coisa rara. E então ela estava rindo. Era um riso como somente quem não fala ri. Esse riso, o explorador constrangido não conseguiu classificar. E ela continuou fruindo o próprio riso macio, ela que não estava sendo devorada. Não ser devorado é o sentimento mais perfeito. Não ser devorado é o objetivo secreto de toda uma vida. Enquanto ela não estava sendo comida, seu riso bestial era tão delicado como é delicada a alegria. O explorador estava atrapalhado.
\end{abstract}

(Clarice Lispector, 1974)

Este artigo discorrerá sobre a questão do riso na psicose, não se centrando nas diferenciações entre riso sorriso e gargalhada, e sim nas que Freud apresentou em relação ao risível: os chistes, o cômico e o humor. Os conceitos que o fundamentam são o de psicose, riso, voz e sideração no desenvolvimento que Ihes dá Lacan.

Falaremos, então, do riso, em sua assunção no registro do cômico, e da colocação em questão de se haveria aí algo de um efeito sujeito na psicose. Há neste texto questões que são de sua feitura, que não se respondem, e uma que the perpassa: que é do sujeito na psicose? Aquele parasitado pela linguagem, furado, sujeito da falta e do desejo que aí se move. Nos centraremos ainda em conceitos como os de Outro, significante fálico e imagem na psicose para embasar a discussão aqui proposta.

As questões que suscitaram o desenvolvimento desse texto estão nele inscritas e advieram de um atendimento clínico com um menino de mais de cinco anos que ainda não articulava falas. Os atendimentos sempre se davam em espaços coletivos, pois para ele era impossível permanecer em uma sala fechada, e eram recheados de risos e gargalhadas.

O toque leve excita a pele. Os pêlos se eriçam, os músculos se contraem desordenadamente, a boca se abre, a voz repetindo intensa se esvai. Cócegas são ao corpo alegrias. Quando o atrito se dá entre pele e palavra, afinal o inconsciente é o superficial, em uma cadeia cuja lei, que a regeria mais-além do prazer, foi extirpada, o que faz graça? No constituído na imagem biunívoca, empedrada, que não faz senão se repetir, qual a graça da queda, do inesperado em uma cena que se 
desenrola? Seria o riso um momento de queda da voz; um encontro furtivo, ligeiro, possível?

\section{Desenvolvimento teórico}

Procura perturbar, os homens, por primeiro, Saciá-los? Um difícil e atroz empreendimento.

(Goethe)

"No começo era o verbo", diz-nos a Bíblia, e então Deus disse faça-se luz engendrando o mundo e nele as diferenças: dia quando há luz; noite quando não há. Depois criou o homem de quem da costela forjou a mulher e thes deu o poder de nomear as coisas que havia criado. No Éden, dizem-nos os teólogos, pairava a harmonia, não havia falta, a diferença sexual não era questão: estavam ali Adão e Eva nus, sem qualquer rumor de vergonha ou desejos, belos e jovens, imperecíveis; ninguém ria no Éden. Até que Eva come da árvore do conhecimento, o fruto proibido: o desequilíbrio se dá. É só então que, ao entrever a nudez de Adão, ela ri. Decaídos, Adão e Eva, não mais imagem e semelhança de seu criador e sim frutos do pecado incitado pelo maligno, aí representado pela cobra bem-falante, viram mortalmente insatisfeitos e vão viver o martírio da busca de satisfação.

"É esse hiato entre a existência e a essência que provoca o riso, essa defasagem permanente entre o que somos e o que deveríamos ser" (MINOIS, 2003, p. 112). Adão e Eva já não são o que deveriam ser, a imagem deles já não é a de deus, e o que eles vêem agora pode ser motivo de riso.

Nessa queda há o Pai que, onisciente, castiga cortando o gozo quando esse outro sabor se faz sentir na boca de Eva, evidenciando assim o furo no saber e abrindo o campo do desejo. Pai onividente, que vai perturbar Adão perguntando-Ihe “Onde está você?". Didier-Weill (1997b), em importante contribuição, aponta-nos uma questão que aí está colocada: há algo que o todo-poderoso também não sabe. Ainda que possa ver Adão em seu pretenso esconderijo, deus não descobre desde onde este se esconde nem o lugar do qual, justamente por não o saber, Adão vai tomar a palavra. Conhecedor do esconderijo especular, o próprio deus aponta que há um outro, metafórico, do qual nada sabe. Adão treme, teme perante esse ser a quem não pode dizer nem sim nem não: fica siderado. De que se trata na sideração? Trata-se na neurose de um instante em que a presença no discurso de um significante alheio ao saber inconsciente desorienta:

ela (a desorientação) é tanto de ordem espaço-temporal quanto de ordem ética: não sei mais onde está o bem e o mal (é a 
questão do real), não sei mais onde está meu corpo na medida em que se tornou transparente perante o olhar do Outro (é a questão do imaginário), não sei mais responder ao Outro (é a questão do simbólico) (DIDIER-WEILL, 1997b, p. 196).

Em seu livro sobre os chistes, Freud situa a sideração (Verblüffung) nesse momento em que, no próprio jogo da linguagem, se passa do sentido ao não-sentido e diz que o riso que ele produz se dá no momento seguinte, momento no qual o reconhecimento do outro, que apareceria no próprio riso, traria sentido ao não-sentido. É nesse sentido sua observação de que certas ditos são engraçados apenas a certas paróquias, pois é preciso que se partilhe um certo código para poder mergulhar em seus sentidos e não-sentidos sem ficar totalmente perdido (FREUD, 1905/1977).

A sideração então, é um momento de perturbação do qual se sai pelo efeito significante que se passa no coletivo. Didier-Weil em seu livro Os três tempos da lei (1997b) vai apresentá-la em três maneiras diferentes: na primeira o sujeito seria tomado de surpresa e só conseguiria responder por negativas: “É incrivel!, inacreditável!"; na segunda, que ele denomina espanto ou temor, a perturbação chega a tal ponto que o sujeito, por um momento, perde a voz; já na terceira, especificada como estupor, a perda de voz perdura, e o sujeito não mais responde, segundo Didier-Weil este seria o momento em que o sujeito resta preso ao gozo do Outro.

A sideração é então um momento precioso desde que nele mesmo haja algo disso que Freud (1905/1977) chama a luz que de-sideraria, que, ao se apagar, viesse a fazer falta, e como significante deixasse a desejar (LACAN, 1999). No chiste a saída da sideração se dá então pela autenticação simbólica que trás uma satisfação coletiva e gera o efeito sujeito.

Do perturbado ao saciado, que lacuna há? Quer dizer, o que há entre o perturbado e o saciado que faz esse percurso? Ou ainda, há aí percurso? "É através da busca de uma satisfação passada e ultrapassada que o novo objeto é procurado, e que é encontrado e apreendido noutra parte que não o ponto onde se o procura" (LACAN, 1995, p. 13). Se o especular não for quebrado por uma voz, que nomeie o que vemos e nisso nos tire da sideração provocada pelo desconhecido, manterá o sujeito preso à condição de objeto de gozo em uma relação calcada estritamente pela demanda. Ao sujeito, então, preso à sideração do biunívoco é impedido de-siderar, ou seja de: “'cessar de ver' e 'lamentar a ausência de..' - donde 'desejar'“(DIDIER-WEIL, 1997b, p.118). 


\section{Perder das Ding, entrar na linguagem}

O que nos satisfaz? O que nos perturba? "Nenhuma perfeição de qualquer espécie, nenhuma finalidade interna, à qual se refira a composição do diverso, é posta no fundamento deste juízo" (KANT, 1790/1980, p. 229), qual seja, aquele que Kant denomina juízo-degosto. Tal juízo, estético e subjetivo, não pode ter seu fundamento em qualquer conceito. A Analítica do belo é um texto da efervescência da Revolução Francesa, 1790 é seu ano. Tomemos aqui outro texto, que seu autor escrevera nove anos antes: Crítica da razão pura, no qual, ao pensar a possibilidade de uma matemática e uma física puras e da metafísica, se coloca a questão de que o objeto, qualquer que ele seja, não pode ser apreendido enquanto todo: das Ding an sich, mas enquanto objeto em mim.

Freud em seu Projeto de uma psicologia retoma tal conceito ao falar do neurônio para sempre perdido, no qual haveria dela (das Ding - a Coisa) uma representação da qual resta um representante: Vorstellungsrepräsentanz, o que Lacan, calcado na lingüística de Saussure, chamará significante: “Trata-se daquilo que, no inconsciente, representa como signo a representação como função da apreensão - da maneira pela qual toda representação se representa uma vez que ela evoca o bem que das Ding traz consigo" (1995, p. 92).

É também pensando a partir do conceito de das Ding que Lacan, em seu seminário sobre a ética, apontará o incesto enquanto lei fundamental. Segundo ele a mãe ocuparia o lugar de das Ding se aniquilasse a possibilidade de seu filho de desejar, ao não apostar que ele venha a ter pensamentos diferentes dos seus, ou seja, de que há ali, naquele corpo que saiu dela e que ela pode ver, algo que ela não apreende, algo de que não dá conta e ao qual, portanto, tem que dirigir, além de seu saber, perguntas. Se ela não 'cessar de ver' esse corpo, não 'lamentará sua perda' mantendo-o preso. É só porque alguém nos pergunta que respondemos, por não termos como falar tudo que nos pomos a falar. Enfim, é por não possuirmos das Ding que discorremos e buscamos nos relacionar (LACAN, 1997).

A inserção do infans na linguagem acarreta a perda tanto de das Ding quanto do lugar daquele que satisfaria todos os desejos da mãe, ou seja, esse lugar representado pelo significante falo. Essa inserção se dá mesmo antes da criança nascer e vai se efetivando desde os primeiros cuidados que a mãe tem com o bebê. Bergès e Balbo frisam a importância desses momentos para a inscrição significante da criança na linguagem:

É aí que as coisas podem mudar, nos cuidados que ela fornece e 
o que ela vai lhe dizer deslocará a erogeneidade, cortará algo. A mãe, quando articula algo, enquanto cuida de sua criança, pelo que ela the diz, pelo discurso que ela sustenta, introduz o simbólico no tocar (2001, p.65).

A erogeneidade que ela corta é a da auto-satisfação e o discurso que ela sustenta é o que permitirá o jogo metafórico da linguagem.

No campo da linguagem o que permite que se faça metáfora é a substituição desse lugar vazio instaurado pelo irrepresentável (a perda de das Ding) - inicialmente contornado pelo desejo da mãe - pelo significante Nome-do-pai. Este que barra ao Outro, até então encarnado pela mãe, a concessão desse sujeito enquanto objeto de seu gozo, enquanto o que, como sua extensão, a livraria da pena para a qual somos lançados graças ao pecado original: a morte.

$\mathrm{Na}$ psicose a não inscrição desse significante no campo do Outro é o ponto pivô da estruturação, nos diz Lacan:

\begin{abstract}
A Verwerfung será tida por nós, portanto, como foraclusão do significante. No ponto em que, veremos de que maneira, é chamado o Nome-do-Pai, pode pois responder no Outro um puro e simples furo, o qual pela carência do efeito metafórico, provocará um furo correspondente no lugar da significação fálica (1998b, p.564).
\end{abstract}

A falha no Outro se dá, então, no lugar da significação fálica, lugar em que ao ver refletida sua imagem o sujeito poderia tirar seu corpo, ou seja, lugar do qual ao tirar um mínimo de reconhecimento sobre pertencer ao simbólico o sujeito poderia circunscrever um lugar próprio de fala. O que se passa na psicose é que o sujeito não reconhece sua imagem aí pois ela não foi nomeada pelo significante Nome-do-pai, a esse furo o sujeito só pode responder emprestando o próprio corpo, voltaremos a esse ponto.

O significante Nomes-do-pai ao fazer função de metáfora separa o sujeito do Outro abrindo uma hiância que possibilita a tomada da palavra, e ao nomear tira o sujeito da sideração na qual a falta de sentido do desejo da mãe Ihe lança. Ao não ser inscrito no simbólico, esse significante fica circunscrito ao registro do real que Lacan especifica como aquele do impossível de representar. Então, o que se apresenta ao sujeito é a demanda insaciável do Outro que ao não ser metaforizada não permite que ele saia do plano biunívoco, a imagem não podendo se perder (LACAN, 1998b).

Se não perde a imagem de ser aquele que completa a mãe, o que perde o psicótico? Diz-nos Lacan: a liberdade. Em seu texto sobre a 
causalidade psíquica, Lacan imprime à loucura seu estatuto de humana: “Longe de ser para a liberdade um 'insulto', ela é sua mais fiel companheira, e acompanha seu movimento como uma sombra" (LACAN, 1998b, p. 177). O psicótico perde, então, a liberdade não pela falta de um pai, mas pela falta da inscrição da lei que seu nome simbolicamente traria e por esta não ser restituível, aí mesmo a escolha de Lacan pelo termo foraclusão, que no vocabulário jurídico indica o esgotamento do prazo que o sujeito tem para apelar a uma ação. É isso que se produz quando o significante Nomes-do-pai é expulso do registro simbólico e o sujeito fica lançado a um não-sentido.

\title{
A perda de objeto e o riso
}

Não é por pouco que se perde o objeto. Há um preço a pagar, por mais que nos pareça que a palavra nos tenha sido dada de graça. Lembra-nos Didier-Weill (1997b), fomos antes dela do que ela nossa: o que nos permitiria então estranhá-la? Se tivermos que garantir sua existência, como, então, perdê-la na fala? Se "o símbolo se manifesta inicialmente como assassínio da coisa", fechando qualquer caminho que pretensamente a alcançaria, "e essa morte constitui no sujeito a eternização de seu desejo" (LACAN, 1998b, p. 320), abre às diversas formas de falá-la. E é só quando a palavra pode se fazer outra, cair enquanto imagem, que há graça. De que falaremos aqui? Do riso na psicose. Do que será que no caso sobre o qual traremos alguns recortes se perde e do que aí faz graça.

\begin{abstract}
Há de nunca haver observado uma criança em seu desenvolvimento, ao longo dos primeiros meses, para não perceber que, antes mesmo da fala, a primeira comunicação verdadeira, a comunicação para além daquilo que vocês são diante dela como presença simbolizada, é o riso. Antes de qualquer palavra, a criança ri (LACAN, 1999, p. 343).
\end{abstract}

Do gostoso riso dos bebês às gargalhadas assustadoras dos personagens malvados das histórias infantis há, é claro, risadas quase mudas, e aqui nos debruçaremos nas gargalhadas de um menino que quase não fala. Com quem ri o louco ao parecer rir sozinho?

O estudo sobre o riso não é vasto, diversos autores trazem alguns fragmentos, mas poucas obras nele se centraram, há hoje dois livros que versam sobre a história de seu estudo: História do riso e do escárnio, de Georges Minois, e O riso e o risível na história do pensamento, de Verna Alberti (2002). Na filosofia temos Bérgson, que nos traz o riso como algo da ordem do social. "O homem é o único animal que ri", diz Aristóteles (1999) em As partes dos animais 
imprimindo ao riso valor ímpar, para depois nos falar da fisiologia do riso, que tem como elemento principal o diafragma. Vemos em diversos autores essa referência às afecções corporais do riso, há o calor, o rubor, - estremecimento e até algumas minuciosas descrições das transformações da expressão facial. A busca por estudos acerca do risível acaba por nos remeter ao livro perdido de Aristóteles, em que algo da comédia estaria escrito.

O estudo do riso no campo da psicanálise tampouco tem lugar de destaque. Aclamado por Lacan, o livro de Freud Witz, segundo Jones (1989), era desprezado pelo próprio autor como livro secundário.

Já em sua Retórica, Aristóteles (2006) coloca a questão que será retomada por Freud: os jogos da linguagem, a troca de letras, a aglutinação de palavras, os diferentes sentidos das palavras dizendo que a coisa deve estar evidente no momento mesmo em que é dita, e aqui nos parece mais próxima da escrita posterior de Freud (1927/1996) sobre o humor em que o sujeito assumiria o lugar daquele que tem o domínio para, justamente, dele zombar, para zombar de sua própria perenidade. Já no chiste, Freud (1905/1977) aponta e Lacan (1999) desenvolve a questão da assunção da função subversiva que a fala exerce no campo que a precede aquele da linguagem e suas regras. É justamente por usar dessas mesmas regras para burlar o que delas a organiza que a fala ganha aí estatuto irrevogável de verdade, de uma verdade simbolicamente autenticada pelo Outro, este que é, então, corolário daquele que o subverte: o sujeito. No chiste há um Outro passível de falha, em que há um furo irremediável, lugar da lei, que, ao barrar a sideração, dá luz ao desejo do sujeito.

Na psicose a falha do Outro se dá na inscrição daquilo que daria ao sujeito um lugar de enunciação, daí o estranhamento do sujeito em relação às palavras. A sideração, enquanto perda de voz, na psicose é contínua: o Outro está sempre presente - enquanto na neurose o sujeito se protege dele em seus engodos, na psicose não há esconderijo: a metáfora paterna fracassou. Como então pensar o riso nessa estrutura? O louco, dizem, ri sozinho. Ao que se pode perguntar: como riria sozinho quem está continuamente tomado pelo Outro?

\section{A boca e a voz}

O riso é algo que nos sai pela boca, nos sai pela boca para voltar pelos ouvidos, mas que ele saia, isso é irremediável, implica que a voz se perca. A princípio pode não nos parecer essa voz de que Lacan (2005a) fala enquanto voz incorporada, articulada enquanto fala, podem nos parecer apenas sons, e o engraçado é que não o parecem. O fato, e falo de fato enquanto algo que nos afeta o corpo, é que algo ali nos toma, e 
nos toma em uma dimensão em que não temos o que dizer, em uma dimensão em que, de alguma forma, o que ali se passa em nós ecoa.

Esse eco pode nos deixar atrapalhados, estupefatos, siderados, afinal, é um riso que não sabemos de onde vem, não partilhamos de sua eclosão, estamos excluídos dele. Na busca de reconhecer o risível, eis que nos perdemos e que estranhamos.

Kant contempla a questão do riso dizendo: "O riso é uma afecção decorrente da súbita transformação de uma expectativa tensa em nada", (1790/1980, p. 266) de um absurdo inicial percebido a tentativa de entendê-lo até a percepção de que era um equívoco do qual o entendimento fica apartado e sem dívidas. O riso é, então, um tipo de alívio, uma liberação de prazer advinda do livrar-se da tensão. Freud em alguns momentos nos parece kantiano, mas ele segue, suas formulações não param por aí, e ele chega a algo que nomeia o mais além do princípio do prazer (FREUD, 1920/2006). Já não estamos mais apenas na busca por alívio, há algo que nos faz repetir infinitamente que Lacan (1992), mais tarde, chamará o campo do gozo.

Este apresenta o perigo de deixar o sujeito siderado, governado pelo Outro, ou se pondo em sacrifício para lhe autentificar uma existência. Se resta preso a esse campo o sujeito é tomado pela terceira forma de sideração de que nos fala Didier-Weil, o estupor, frente ao não-sentido que a inserção na linguagem o deixa ele perde a voz. O que pode fundar o sujeito pode também impedir que ele surja, ou seja, pode impedir que ele partilhe do sentido coletivo ao torná-lo escravo de um jogo significante em que a significação fálica não se inscreve. O Outro é, enfim, um tesouro atrás do qual se corre desde que jamais se chegue a encontrá-lo.

O Outro enquanto tesouro dos significantes, ou seja, enquanto campo da linguagem é o que cada falante vai defender e do que terá que se defender. A fala se constitui enquanto defesa possível contra este parasita que é a linguagem e Anna $O$. se pronuncia dizendo a Freud que se cale, imprimindo à psicanálise seu estatuto: o tratamento das perturbações trazidas pela linguagem através da fala. Para diferenciarse do universal de animal falante cabe a cada um usar da voz. Nesse movimento a voz não se equivale ao significante, é o que, ao articulá-lo enquanto fala, resta ao final do esforço por significar (LACAN, 2005a).

Lacan, ao falar da voz em seu seminário sobre a angústia, começa falando do aparelho auditivo, do que chama o tubo, a cóclea, que é caixa de ressonância, para logo em seguida falar da flauta, um tubo com buracos seqüenciais. Segundo ele a voz ressoa não em qualquer vazio, mas no vazio do Outro: 
A voz responde ao que é dito, mas não pode responder por isso. Em outras palavras, para que ela responda, devemos incorporar a voz como a alteridade do que é dito [...] É próprio da estrutura do Outro constituir um certo vazio, o vazio de sua falta de garantia (LACAN, 2005a, p. 300).

$\mathrm{Na}$ boca do Outro, se não for falado enquanto alteridade, o sujeito fica preso. Uma das coisas que nos ensinam os chistes é que não se dá efeito de significante se não há endereçamento, ou seja, que para que se dê riso, satisfação coletiva, é preciso que haja um reconhecimento de todos do efeito que a fala tem sobre a linguagem, esse efeito é o que Lacan chama de efeito sujeito. Porém, se a boca a que cabe endereçar ao ainda não falante o código que permite a fala, for plena de uma verdade infalível, a voz que dela sai não inscreverá nada, pois não precisará se endereçar a ninguém, não precisará perguntar nada a ninguém. Da pura voz, não endereçada, não caem letras, não havendo, então, o que estas permitem: da amarração entre voz e linguagem, o litoral entre gozo e saber, e daí a possibilidade, ou mais, o imperativo de uma queda do objeto. A voz não pode cair se a significação fálica está recoberta pelo corpo do sujeito. O que se perpetua então é uma presentificação de das Ding imprimindo o gozo exclusivo do saber do Outro ao qual o psicótico não tem como responder.

Continuemos com a metáfora da boca: não se trata da laringe ou das cordas vocais ou ainda do diafragma ou do que mais faça parte desse sistema porque o que nos importa é o furo, a borda dos lábios, o homérico recinto dos dentes (LACAN, 2005a). Pois aí algo de uma perda se evidencia, algo de uma perda indelével, com a qual o falante pode ou não se defrontar. Na psicose o Outro não abre a boca. Não que ele não fale, ele fala e fala à revelia do sujeito, este que está dentro de sua boca fechada, saciada por esse corpo que lhe tapa o buraco.

Sem ter nomeado seu corpo, recalcada sua excitação, que só então faria curiosidade, o psicótico resta impossibilitado de conhecer a diferença sexual e nela esse furo, esse vazio, tão aparente no real do órgão sexual feminino, que Ihe evidenciaria a falta. Assim, a imagem da mãe enquanto perfeita não cai, ela continua não castrada, ou seja, a ela nada falta, seu saber não pode ser contestado. Ao sujeito resta repetir aquilo que lhe é dito e ele então não pode formular sua teoria sexual, não podendo localizar-se naquilo que diz. O Outro fala nele, ele fala pelo Outro, este ser único onde o saber suposto guardaria sua verdade. Dessa voz que assim se lhe dirige resta-Ihe a auto-satisfação, ela não cai enquanto objeto, não pode ser perdida, permanece muda ou não corporificada, (BERGĖS; BALBO, 2001) ela é incorporada enquanto puro mandamento. O sujeito estará sempre obediente ou convicto ao que 
essa voz, que é a via pela qual recebeu algo do Outro, Ihe diz (LACAN, 2005a).

De que ri esse sujeito?

\section{A queda da imagem e o riso}

Recortemos algo do que instigou este trabalho. Hércules não falava, tinha algumas vocalizações, por vezes melódicas, por outras se anunciava uma palavra, uma tentativa de palavra, um "tá!", um "no", "abe!" impositiva. Suas risadas advinham de jogos corporais, da velocidade do skate, de andar para trás nele, de jogar carrinhos longe, de correr pela rua, de assistir a algumas cenas entre outras crianças. Não diríamos que aqui há algo do humor, desse que Freud escreve magistralmente em uma frase enquanto um: "identificar-se até certo ponto com o pai" (FREUD, 1927/1996, p. 167), tampouco aos jogos de linguagem presentes nos chistes. Tangenciamos então o outro, identificado por Freud, motivo de riso: o cômico. O que nos diz Freud e antes dele outros pensadores: o cômico é motivador do riso por meio da ação, do ver ou participar de uma cena inusitada, em que algo ia bem até que... Lacan em seu quinto seminário fala do riso no cômico:

O riso eclode na medida em que em nossa imaginação o personagem imaginário continua sua marcha enquanto que o que o sustenta de real fica ali, plantado e esborrachado no chão. Trata-se sempre de uma liberação da imagem. Entendam isso nos dois sentidos desse termo ambíguo - por um lado, alguma coisa é liberada da coerção da imagem, e por outro, a imagem também vai passear sozinha (LACAN, 1999, p. 137).

O riso é aqui fenômeno imaginário e não, como no chiste, simbólico. Percorramos então ainda um pequeno percurso para que as noções de imaginário e de belo ajudem a pensar essa queda da imagem de que nos fala Lacan.

A verdadeira barreira que detém o sujeito diante do campo inominável do desejo radical uma vez que é o campo da destruição absoluta, da destruição para além da putrefação, é o fenômeno estético propriamente dito uma vez que é identificável com a experiência do belo - o belo em seu brilho resplandecente, esse belo que disseram que é o esplendor da verdade. É evidentemente por o verdadeiro não ser muito bonito de se ver, que o belo é, senão seu esplendor, pelo menos sua cobertura (LACAN, 1997, p. 265).

Para Lacan o belo não é das Ding - o bem-supremo - e, portanto, não é o que cessaria nosso desejo, mas sim aquilo que pode enganar quanto a 
isso, na medida em que descarta o objeto. Se no belo não há mais o que se buscar é por ele sobrepor uma imagem à hiância que há entre o que "somos e o que deveríamos ser". É como um momento de volta ao paraíso cristão, volta ao tempo em que nossa imagem corresponderia à imagem de deus. Esse tempo de que falamos no inicio do artigo é o tempo da biunivocidade, ou seja, da equivalência ponto a ponto sem ponto cego, sem equivoco. Uma hipótese é que na psicose o sujeito não conseguisse se desprender do discurso do Outro. Desta forma, o imaginário, forçado a uma correspondência ponto por ponta com o discurso do Outro, produziria uma sideração quase inescapável.

Introduzamos o mito: Narciso é um bebê magnífico, sua mãe chega a se espantar e a temer a fúria dos deuses contra seu filho e vai buscar junto ao sábio Tirésias alguma luz sobre o destino da criança. Viverá até idade avançada tão linda criatura? Tirésias the responde: "Sim, se não se conhecer". Narciso cresce e certo dia, ao se perder de sua trupe, em sua aventura de caçadores, começa por chamá-los, perguntando "alguém está?" ao que, além da sua, uma voz lhe respondia "Está". Outra das peripécias da vingativa deusa Juno àqueles que lhe desafiam ou engodam em relação a seu amor: Eco: a ninfa que, eloqüente, a dispersava de suas buscas por Júpiter, sua condenação o diminuto uso da voz apenas reportando palavras ouvidas (OVÍDIO, 2003).

A mãe de Narciso temerosa das previsões do sábio Tirésias tirou todos os espelhos da casa para que seu filho jamais se conhecesse. É esse saber absoluto que Ihe foi profetizado que ela guarda para si e que faz com que jamais apresente ao filho a imagem que os outros vêem quando Ihe miram. Essa imagem para a qual ele não tem, então, um nome. Há aí algo do que concerne a estruturação psicótica: um saber absoluto que não pode ser contestado e que cai sobre o sujeito como certeza e o buraco que este deixa ao vetar a nomeação e conseqüente a queda da imagem que esta acarretaria. A mãe que ao fazer apelo a um outro sobre o destino de seu filho recebe como resposta um significante mortífero e não consegue fazer valer a metáfora paterna. Esse saber pode não ser sabido pelo sujeito que o recebe, ou seja, pode ser inconsciente e é daí que tira forças para, a revelia do sujeito, se realizar. Eco não satisfaz Narciso que foge dela até encontrar um lago em que nenhuma imagem antes se refletira. Aquele que Narciso encontra ao se debruçar para beber água é quem Ihe apraz. Depois de enamorado, das tentativas inglórias de alcançar seu amado, Narciso se conhece (OVIDIO, 2003). Momento preciso e nos perguntamos se então já não é à imagem que Narciso está preso, não mais à beleza, mas ao próprio olhar. Teria ele transposto a última barreira? Seria ele presa do olhar do Outro, vetado a olhar aquilo que não pode olhar de si mesmo? Ou seja, 
de ter seu próprio olhar? Se Narciso não pode ter sua beleza é porque a imagem que ele vê não é nomeada e portanto não pode cair sendo siderante. A metáfora paterna fracassou e é por a Coisa estar ali presente, que ele tem a certeza de não poder se mexer, pois se o fizesse a mataria - para matá-la teria que apelar ao simbólico que, justamente, aí lhe falta - e é então que ele se mata. Narciso é um louco, siderado pelo olhar do Outro, paralisado na pulsão de morte (BERGÉS; BALBO, 2001).

Eco que já não podia se fazer ouvir não mais se faz olhar: não tem mais como vir a ter nem palavra nem corpo que um não se faz sem o outro (BERGĖS; BALBO, 2001). Essa falta de nomeação pelo Nome-do-pai de que sofre o psicótico (LACAN, 1974/75) faz dele prisioneiro da demanda insaciável de um Outro que não cessa de se presentificar (LACAN,2002).

\title{
O riso cômico na psicose
}

\begin{abstract}
Vemos, segundo meu velho esquema, produzir-se aquilo de que se trata no riso, quando a demanda chega sã e salva, isto é, quando vai para-além da máscara para encontrar ali não a satisfação, mas a mensagem da presença. Quando o sujeito passa um recibo de que tem diante de si a fonte de todos os bens, o riso certamente eclode, e o processo não precisa seguir adiante (LACAN, 1999, p. 344).
\end{abstract}

E quando não se dá a metonímia da demanda que em seu movimento engendraria o desejo? Quando se trata de um bem que responde a tudo, que de tão presente não cessa de perturbar o sujeito, onde vamos parar? O problema na psicose é que nesse ponto não se pára. Não se pára frente a esse corpo que está aí e que é, de todas as maneiras, evidente. Ele faz barulhos, de todas as espécies, que saem de diferentes buracos, e nos dizem Bergés e Balbo que "É no momento em que a mãe transforma os barulhos da criança em algo da ordem da fala é que justamente se passa do imaginário ao simbólico" (2001, p.145). Essa fala, eles caracterizam como fala da mãe que passa então a ver o filho não mais como extensão de sua imagem, mas como outro como corpo diferente do dela e diferente da imagem que ela lhe emprestou (idem). Nessa hiância, o significante falo que é aquele que "nunca está realmente ali onde está, e nunca está completamente ausente ali onde não está" (LACAN, 1995, p.197) pode se esvaziar da imagem do filho e ir buscar outras.

No cômico a queda do significante falo de seu lugar de potência inabalável é o que tira o sujeito da biunivocidade em que o olhar siderante lhe aponta um todo sempre igual (LACAN, 1999). Admite-se a 
morte, e não há como resolvê-la, aí o próprio sujeito se vê sozinho, o desejo de morte quebrantado tem de procurar outras vias (LACAN, 1997). O riso é então um barulho que a boca emite e um frêmito que o corpo sente. É um barulho reconhecível, diferenciável, que ao se dar no momento de uma queda podemos especificar enquanto algo que faz marca.

\begin{abstract}
O psicótico é um mártir do inconsciente, dando ao termo mártir seu sentido, que é o de testemunhar. [...] O psicótico, no sentido em que ele é, numa primeira aproximação, testemunha aberta, parece fixado, imobilizado numa posição que o coloca sem condições de restaurar autenticamente o sentido do que ele testemunha, e partilhá-lo no discurso dos outros (LACAN, 2002, p. 153).
\end{abstract}

O sujeito tomado pela pulsão de morte parece não conseguir escapar ao desejo que ela engendra, pois não pode articulá-lo em fala. Está preso a ocupar com o próprio corpo o lugar do significante falo. E quando o riso inusitado eclode, qual o lugar do analista aí? Se supomos que há aí algo de uma marca que pode se tornar caminho, abrir a possibilidade de partilhar um sentido, é aí que pode haver ato analítico, desde que o analista tenha uma suposição de sujeito no analisante, é aí que vai se dar seu ato.

O riso nos traz algo dessa surpresa e a dificuldade de saber o que se passa quando de sua assunção parece ímpar à clínica das psicoses. Há de se atentar a esse riso, que parece sem sentido, visto ser ele disparado por uma queda seja ela de uma imagem ou de uma certeza.

Se é nisso que surpreende que o analista deve saber que se trata de algo do inconsciente que se apresenta, não quer dizer que isso baste, que seu lugar se cubra com os poderes gloriosos de interpretação. 0 que desaparece desde que esteja no lugar de analista é sua pessoa (LACAN, 1997) pode ser que aí mesmo o inconsciente se feche, que a transferência, como diz Lacan (1998a), seja esse fechamento e é justamente nisso que o analista não tem como saber que seu ato toma status ético e que, ao não suturar o furo do sujeito com uma teoria que daria conta de tudo, sua busca e produção teóricas hão de se dar.

\title{
Considerações finais
}

O toque da palavra pode não ser leve, pode ser um golpe, golpe de força que força o sujeito à fala (BERGĖS; BALBO, 2002). A cena que se desenrola pode enrolá-lo, ou fazê-lo rolar, de rir. Uma hipótese que há nesse trabalho é de que nesse riso sobre o qual escrevemos há algo de um instante precioso para a clínica das psicoses. 
Haveria, então, no riso cômico um vislumbre de uma queda da imagem que por um momento tiraria o sujeito da sideração. O efeito sujeito não aparece aí, pois não há compartilhamento, reconhecimento de algum sentido no não-sentido. O que nos faz relançar a questão: como pensar o fenômeno do riso na transferência? Há como fazer desse riso laço?

\section{Referências Bibliográficas}

ALBERTI, V. O riso e o risível - na história do pensamento. Rio de J aneiro: J. Zahar, 2002.

ARISTÓTELES. A retórica. Lisboa: Imprensa Nacional-Casa da Moeda, 2006.

As Partes dos Animais, Livro I. In:Cadernos de História e Filosofia da Ciência, Campinas: Série vol. 9, n. especial, 1999, pp; 1144.

BERGÈS, J.; BALBO, G. Seminário I, A atualidade das teorias sexuais infantis. Porto Alegre: CMC, 2001.

Jogo de Posições da mãe e da criança - ensaio sobre o transitivismo. Porto Alegre: CMC, 2002.

. Os três tempos da lei. Rio de Janeiro: J. Zahar Editor, 1997b.

FREUD, S. Projeto de uma psicologia [1895]. Rio de Janeiro: Imago, 1995.

.O humor [1927]. In: O futuro de uma ilusão e outros trabalhos. Rio de J aneiro: I mago, 1996, p.163-169.

O chiste e sua relação com o inconsciente [1905]. Rio de Janeiro: I mago, 1977.

Além do princípio de prazer [1920]. In: Escritos sobre a psícologia do inconsciente - Volume II: 1915-1920. Rio de Janeiro: Imago, 2006, p.123-180.

JONES, E. A vida e a obra de Sigmund Freud, vol.2. Rio de Janeiro: Imago, 1989.

KANT, E. Os pensadores: Kant II. São Paulo: Abril Cultural, 1980.

LACAN, J. O Seminário, Livro III: As psicoses [1955-56]. Rio de Janeiro: J. Zahar, 2002.

O Seminário, Livro IV: A relação de objeto [1956-57] Rio de Janeiro: J. Zahar, 1995.

O Seminário, Livro V: As formações do inconsciente [1957-58] Rio de Janeiro: J. Zahar, 1999.

. O Seminário, Livro VII: A ética da psicanálise [1959-60]. Rio de Janeiro: J. Zahar, 1997.

O Seminário, Livro X: A Angústia [1962-63]. Rio de Janeiro: J . Z̄àar, 2005a. 
. O Seminário, Livro $\mathbf{X I}$ : Os quatro conceitos fundamentais da psicanálise [1963-64]. Rio de Janeiro: J. Zahar, 1998a.

. O Seminário, Livro XVII: O avesso da psicanálise [1969-70]. Rio de Janeiro: J. Zahar, 1992.

. Escritos, Rio de Janeiro: J. Zahar, 1998b.

LISPECTOR,C. A menor mulher do mundo. In: Laços de Família. São Paulo: co-edição J. Olympio, Civilização Brasileira e Três, 1974, p.70-77. MINOIS, G. História do riso e do escárnio. São Paulo: Unesp, 2003 OVÍDIO. As metamorfoses. São Paulo: Madras, 2003

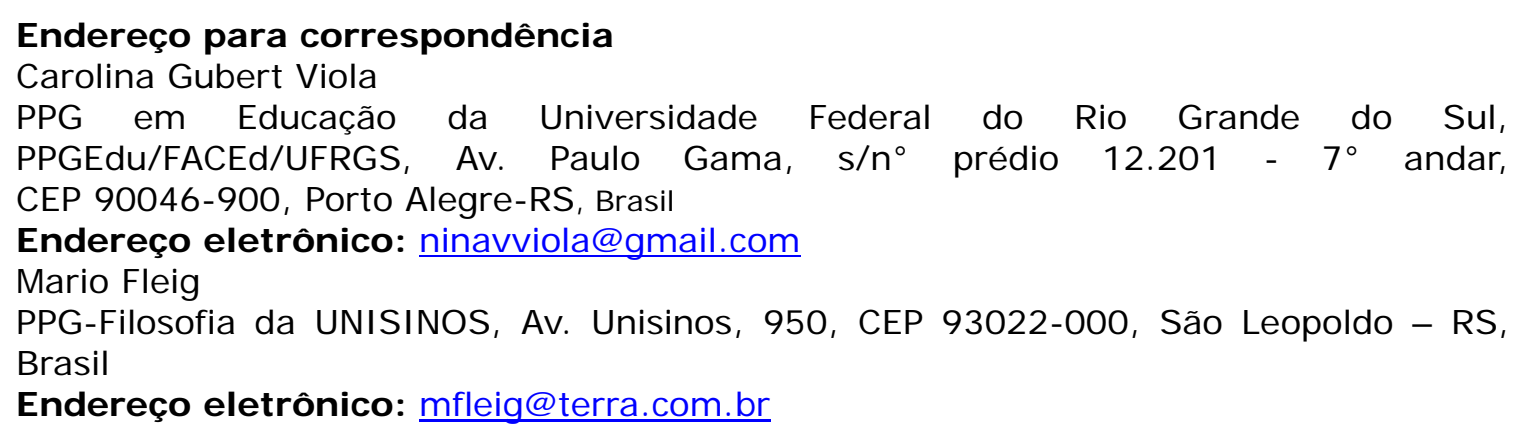

\section{Notas}

* Psicóloga formada pela Universidade do Vale do Rio dos Sinos; bolsista CNPq

** Psicanalista, membro da Association Lacanienne Internationale e da Escola de Estudos Psicanalíticos; psicólogo clínico. 